\title{
The Evolvement of the Israeli Grandmother - As Reflected in Children's Book Illustrations
}

\author{
Nitsa Dori ${ }^{1}$ \\ ${ }^{1}$ Early Childhood Education Department, Shaanan Academic Religious Teachers' College, Haifa, Israel \\ Correspondence: Nitsa Dori, Early Childhood Education Department, Shaanan Academic Religious Teachers' \\ College, Haifa, Israel. E-mail: nitsa.dori@gmail.com
}

Received: September 27, 2021

Accepted: November 11, 2021

Online Published: December 1, 2021

doi:10.20849/ajsss.v6i5.957

URL: https://doi.org/10.20849/ajsss.v6i5.957

\begin{abstract}
Gender and ageism as mirrored in illustrations of grandmothers in Hebrew children's books (1930-2020), shed light on the Israeli reality, which shows the world's portrayal of grandmothers as sometimes empowering and sometimes discriminatory. This article draws from the fields of the visual arts, gender studies, sociology, and culture, and emphasizes the power of illustration in children's literature as an activistic tool for changing social and familial awareness among young receivers. The grandmother (and, recently, also the grandfather) is a popular character in children's literature. The article will present models which shape the consciousness of children's book illustrators regarding old age with the aid of many visual examples. This article will enable deeper understanding of the gender-based messages and effects of visual interpretation. This study can serve as a tool for educators and parents, to help children develop critical, independent, and value-based thinking. The article concludes that in today's books, grandmothers appear more connected to advanced technology than ever. The illustrators of today's children's books connect with the model of the new grandmother and draw her wearing jeans and without wrinkles. In parallel, we also see traditionally-portrayed grandmothers in certain illustrations in recent books, from a post-feminist, rather than stereotypical, approach.
\end{abstract}

Keywords: grandmother, ageism, children's books, old age, sexism, denial of old age

\section{Literature Review}

\section{Gender Role and Gender Identity}

Gender is a separate structure than sex, and has separate effects and consequences, beyond the division between sexes (Shani 2019). These developmental processes, of boys and girls, are encouraged by a social atmosphere which validates dichotomous thinking about men and women, body and soul, intellect and emotion, with masculinity linked to the body and intellect - elements which are socially sacred and considered higher and desirable, while femininity is linked to the soul and emotion - considered of lesser importance (Gilligan 2011). Gender role describes all the behaviors, traits and expectations from one of the sexes, based on sociocultural norms (Eagly 1987; Lindsey 2015); when people integrate these social definitions into their self, gender identity is created. During the 21 st century, positions regarding femininity and masculinity continue to be shaped and changed, alongside the maintenance of traditional beliefs regarding gender roles. While egalitarian and various households are created and sexual and gender freedom expands (Lindsey 2015) it would still seem that sex, gender and age can be primary foci in creating an attitude towards the body, embodying self-identity (Shani 2019).

\section{Gender and Old Age}

In his story "Hashanim Hatovot", Shay Agnon (1959) describes a wondrous family which controls time, and the older the heroes of the story get, the younger their bodies become. This is a Jerusalem family where the youngest member is defined as the "elder" whereas his grandfather, aged 93, is described as a young boy. Whether intentionally or not, Agnon's short story holds a dialogue with the physical model of the New Jew created by Zionism, from the school of Nordau. Unlike the Zionist model which creates an inverse connection between physicality and intellect, Agnon creates a simple, even utopic, congruence between the two. The healthy bodies, which become steadily younger, of the family fathers, serve as proof of the intellectual and spiritual lives which were lived as they should be. Old age frequently invites two situations - many changes in the old person's body, 
which distance him from the standards of the model of beauty which sanctifies youth, and entry into a disadvantaged social group. The population of old people is frequently seen socially as needy, weak and supported, an image which explains why many old people oppose their being defined as such, and who feel younger than their chronological age. Old age was even given the literary name "feminization of old age" due to the similarity between the characteristics of old people and those socially accepted as feminine and inferior (Shani 2019).

Art and philosophy in the feminist field create a unique bond, resulting in a relationship of reciprocal fertilization. This bond affects areas outside the field of art and theory: social, political and economic structures, and the personal lives of men and women. The world population is rapidly aging. This accelerated aging is caused by a variety of factors, such as increased life expectancy, better medical services, relative demographic changes, and reduced fertility rates and number of live births. These changes are recognizable not only in developed Western countries such as the USA, Canada, the Scandinavian countries, Germany and France, but also in developing countries such as China and India. Israel is also getting older, and is doing so relatively quickly. As a country which began as extremely young, with only a very small percentage of its population being over 65 , in a relatively short time it has undergone a rapid aging process. These demographic trends are likely to noticeably effect the short-term and long-term in many ways.

\section{Gender and Being a Grandmother}

In the past, most grandmothers were housewives. In our times, they work, have successful careers, study, and are involved in leisure activities and volunteering. Grandmothers and grandfathers are aware of their health and appearance and devote time, efforts, and resources to sporting activities. They are no longer "weak old people" but rather see themselves as being at the pinnacle of their strength and are not willing to give up activities and having fun. In the past, when sex and gender were considered parallel and complementary terms, gender roles were considered shaped in childhood and fixed throughout a lifetime. During the 1960s and 1970s, the Lifespan Developmental Approach developed, which argues that gender roles change and develop throughout life (Lemaster, Delaney, \& Strough 2017). Today's grandmother is also her adult grandchildren's best friend. During these decades, with the increase in life expectancy, we can see many grandmothers and grandfathers who are still helping their own elderly parents. We can even thus say that the many roles of grandmothers and grandfathers are far more varied than in the past. In general, the differences between men and women in gender roles have become smaller over the past 40 years although they still exist.

In our time, being a grandmother is for a long period of time and high life expectancy can sometimes lead to 30-40 years of grandparenting grandchildren (and even great-grandchildren) who are not only babies and little children. The relationships between grandfathers and grandmothers and their grandchildren are positive, but complex. This is a kind of new version of parenting, without the intervention in raising the child. The grandmother/ grandfather see in their grandchild a figure which imparts life and creates continuity to the next generation. People do not choose to enter these roles, but after they have, many social norms determine how they should fulfill their role. (Babysitting? Gifts? Educating? Quality time?) (Brick and Lowenstein 2008). Along with the rise in life expectancy, and the improvement in quality of life, came the wish to continue achieving and developing: courses, returning to university, new careers. Many grandmothers and grandfathers spend more time with their grandchildren than those grandchildren's parents, who need to devote time to their own careers during this period. Undoubtedly, the years of "later maturity" can be a pleasurable and fascinating time... for the grandchildren too. Grandfathers and grandmothers can provide a safety cushion for their grandchildren's emotional state with a nurturing and important addition that is different to that of the parents (Tal-Shitrit 2008).

Grandfathers and grandmothers usually tend to see their continuity in their grandchildren. Being a grandmother imparts them with a symbolic sense of eternity, a link between their personal history and the future, compensation for the disappointments of the past and a feeling of pride in their grandchildren's achievements (Kivnick 1982). Researchers from over 20 years ago demonstrated how the roles of grandparents in Western society have remained undefined, without normative expectations, and without a defined social status while the grandchildren are being raised (Hagestad 1985; Szinovacz 1998). In past theoretical and research-based referral to the multigenerational connections, only limited space was devoted to the contribution made by grandfathers and grandmothers to the nuclear family.

Kivnick (1982) created a five-dimensional conceptualization of the meaning of being a grandmother which added a layer to understanding the role of the grandparent: the dimension of esteem - the Valued Elder, the grandmother with knowledge and resources. Immortality through Clan - preserving the sense of continuity which passes from one generation to the next. Reinvolvement with Personal Past - renewing the connection with 
their own history and the opportunity to relive past experiences. Indulgence - attitudes of warmth and softness to their grandchildren. Centrality - grandparenthood as central to the grandparents' world. We can learn from the above the large number of varieties and dimensions of being a grandparent, and how it is seen as an important and significant role in the familial and social fabric.

In Israel, from the beginning of the 20th century and until the 1970s, grandfathers and grandmothers were painted as being from the Diaspora (Dori 2018/9). They immigrated to Israel with their children and many left behind or lost their parents in the Diaspora. Families who had a grandfather or grandmother were held in awe and people even sometimes kept their distance. Many of those born and who grew up during these times did not merit having living grandparents (Bergson 1987).

Grandparents looked different then - they were wrinkled, and the grandmother wore a housecoat. Their home was also different: antiquated furniture, old photographs, and a distinctive aroma of oldness and homemade food. Most of the grandmothers and some of the grandfathers in those days did not work and were available to look after and babysit their grandchildren. Since they were available, the grandmothers and grandfathers could tell stories or teach their grandchildren skills they had learned, such as how to pray or read from the Torah (for a bar mitzvah ceremony), various handicrafts, knitting, cooking and baking. Grandmother and grandfather were an inseparable part of the family until their death.

\section{Gender and Being a Grandmother in the Illustrations of Hebrew Children's Literature}

An illustrated book is read and written in two languages - verbal and visual. Each of them has different types of presentation and components. Despite the differences between the languages, they have a similar aim - both express an idea using various means of presentation (Hunt 2004; Nikolajeva and Scott 2000, 2001; Nodelman 1988).

In this process of multigenerational culture, children's literature plays a role, recognizable in our times too, and its aim is education and socialization. The illustration is the primary component in children's literature. As a product of the society in which it was created, its culture and values, it uses its visual message to portray those values bearing their figurative, metaphorical, and symbolic significance. There is visual insidiousness, with the visual language carrying out a cunning trick in opposition to the text, imparting it with a different interpretation and expanding the field of the story's interpretation with various visual means and techniques. This is an interesting question for a discussion examining children's literature as a tool which also unites and enhances culture from the aspect of gender.

The importance of the illustration and the visual dimension lies in them being direct elements accessible to young children without the necessity for mediation by an adult. One of a child's basic needs which he can realize through a story is the need for identification. The child's emotional identification with the heroes of the story, with their adventures and fate, leads to subconscious absorption of the values, character traits, and views of the heroes who symbolize them with their personality and deeds (Krasney 2005). Children's books are one of the methods for transmission of culture to children and shaping their viewpoints (Sagan 1995).

The differences between the genders and attitudes toward the "feminine" and "masculine" domains are already recognizable during early childhood. The illustrated book seeks to have the anthropomorphizing power of art used on children, and effects the child and his understanding of his intimate experiences and his attitude towards other people (Schwarcz 2013). In children's books, the illustration is parallel to the written word, demonstrates abstract concepts, emphasizes or contradicts specific aspects of the text or explains and expands its significance with imageries not found in it, enriches the child's associative world, provides him with cultural and symbolic layers of meaning, and develops his aesthetic discrimination ability. The illustration is a "silent communicative dimension" which communicates with the child and the adult reading to him (Tur Gonen 2013).

The grandfathers and grandmothers in children's literature once represented the Diaspora, with their foreign language and closed, rigid culture. They were old, wrinkled, bent over (their pots or books), or sitting in an armchair or on a rocking chair. The only grandparents to be described positively in children's literature of the yishuv (Jewish community in Palestine prior to the establishment of the State) were the veteran farmers of the working yishuv, such as Saba (Grandpa) Eliezer of Eliezer Vehagezer [Eliezer and the carrot] fame (by Levin Kipnis, first published as a poem in 1930 and in book form in 1964).

As opposed to the Diaspora culture, the new culture was secular, agricultural, and of youthful spirit. At the same time, the yishuv excluded two characters from its children's books who frequently featured in the children's literature of the West and Jewish Europe - Grandpa and Grandma. They were absent from the Eretz-Israeli children's literature and did not feature as active figures in the plot, or even as behind the scenes narrators in the 
story, passing it on with love to the young readers.

It is important to note in this context that, aside from religious content, there was no awareness of transmission from one generation to the next using stories. The halutzim (Zionist pioneers) and member of the Zionist Movement wished to cut themselves off from their Diaspora origins and create a - youthful (of course) - New Israeli, who walked proudly upright, and therefore the place of the elderly was missing from the ethos.

Grandfathers and grandmothers who do appear in the children's literature of the past century, were "adopted" by those who had not been privileged to have their own. The grandfathers and grandmothers featuring in most of the stories of the 1970s represent the old generation, who live peacefully with their age and are not in competition with their children's generation regarding property, career, or family status. When the grandchildren came to visit them they were calm and peaceful and enjoyed conversing and explaining things (Baruch, 2008).

The Holocaust and the years following it brought about a sharp change in the attitude of children's literature to grandparents.

The story Simlat Hashabat Shel Hanna'le [Hanna'le's Sabbath Dress], by Yitzhak Schweiger Demiel, first published in 1937, and which became one of the best known and most beloved children's books, is an example of this. The story realizes in both its literary form and plot, the new empathy for the Diaspora, which the teachers and authors wished to arouse among the children of Eretz-Israel after the destruction of European Jewry.

In the post-Second World War years, the grandfathers and grandmothers were still absent from Hebrew children's literature, perhaps because they were outside the immediate experience of families in Israel. The children didn't really ask, and the parents did not hurry to tell and be reminded.

Since rhyming games are also a type of literature, it is important to mention two grandmothers who did appear then, and were "Diaspora-like" in character - one in the well-known finger game, "Savta bishlah daysah" [Grandma cooked porridge] which small children play until this day, and the second "Savta soreget" [Grandma is knitting], that elastic or woolen "cat's cradle" which is used to manipulate knots, and where the grandmother in both is represented as being gray-haired, with glasses and an apron (Dar 2007).

\section{Method}

This article will propose a new way of studying illustrations of grandmothers in children's books - chosen as a representative sample of many other books with pictures of grandmothers, from different periods and divided into various categories. The renewed study will lead to a deeper understanding of the gender-based, social, and cultural messages, and the effect of visual interpretation which can (or probably will) influence the young receiver. This study and discussion, as presented in the article, can serve as a tool for educators, preschool teachers, and parents, to help nurture a person with critical, independent, and value-based thinking. The discussion of visual interpretation in illustrations in the books, that will be brought below, emanates from the assumption that the visual language is parallel to the verbal one, and is based on postmodern and constructive reading of the text and illustration, and on exposing the relationship between them, based on suggested theories for a critical-visual analysis. The study will demonstrate how the encounter between text and illustration becomes a setting for different and varied intergenerational relationships, and will answer the question as to how these intergenerational relationships are portrayed in children's books from different periods, while examining the gender-based, cultural, and social perspective which reflects the complexity of intergenerational relationships throughout the generations.

\section{Findings and Discussion}

\section{Illustrations of grandmothers with glasses, aprons, and headscarves - a feminist protest or a stereotypical worldview?}

"She wears a homey cloth apron over her clothes and is ready to set the table - they jump on me and some pull on my sleeve and some on my apron: Grandma, give us candies, Grandma, give us nuts. Grandma - this and Grandma - that" (Nekhadim, Devorah Baron 1968).

The illustration does not only reflect the artist's talents, but also the sources which influenced him or her, the artist's visual preferences, and the philosophical approach within the society where he or she draws (Tur Gonen 2013). We will discuss three books, from different periods, when grandma was drawn with an apron and headscarf, determining the image of the Diaspora grandmother - in the book Eliezer Vehagezer (1930) by Levin Kipnis (see Figure 1), Savta Mesaperet [Grandma Tells] (1960) by Yitzhak Avnon, illustrated by Pazit Meller Dushi (see Figure 2) and Hahatulim Shel Savta Na'omi [Grandma Naomi's Cats] by Miriam Roth, illustrated by Hila Habkin (2002) (see Figure 3). The three illustrators employ the Diaspora philosophy. 


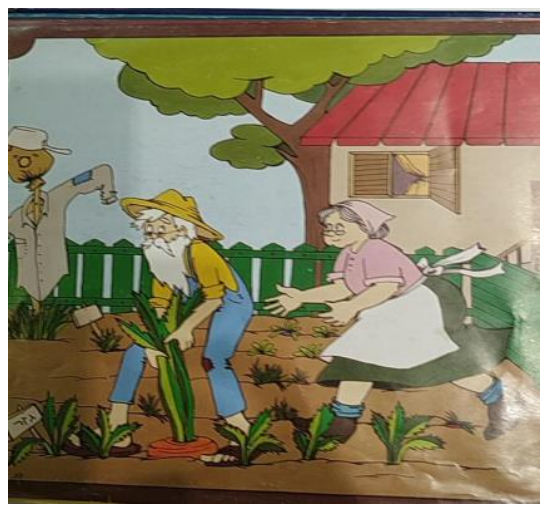

Figure 1. Eliezer Vehagezer - illustration from inside the book

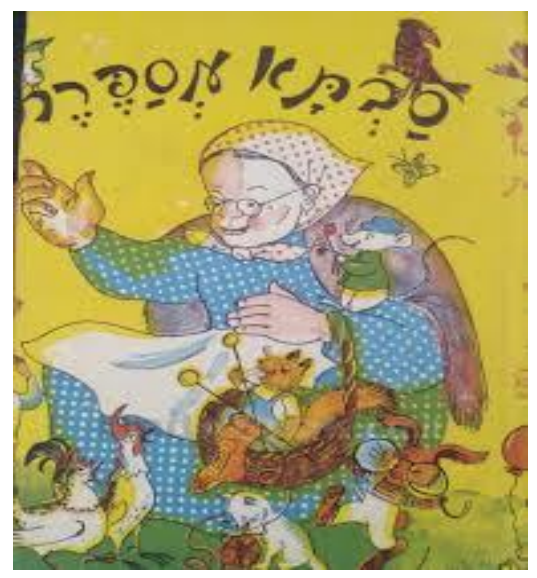

Figure 2. Savta Mesaperet - front cover

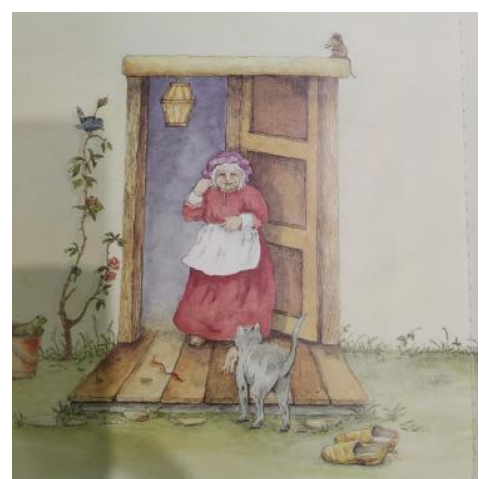

Figure 3. Hahatulim Shel Savta Na'omi - illustration from inside the book

The Zionist Enterprise sought to erase the old, Diaspora, Jew, but it would seem that these three illustrators, along with others, who were asked to draw a "grandmother" in children's books, did not relate to the ethos of negation of the Diaspora as a transformative discourse in structuring Israeli-Jewish identity. They glorified the Diaspora grandmother with her apron, glasses, headscarf, and white hair. When analyzing the mutual relationship between the various bodily dimensions and themselves, and between themselves and other variables, the importance of the gender variable increases. In contrast to men, women are supposed to comply with stringent standards of maintaining a low weight. They are required to work and color their hair, and to employ various practices of working on their bodies to keep them within the pattern which the culture defines as desirable (Liran-Alper and Kama 2007). Culture in today's world overstresses the importance of youth, with all 
that implies. In particular, it allocates many resources to setting a youthful body as a universal object of desire. Young people are placed on a pedestal and embody the pinnacle of beauty, while the yearned-for goal is avoiding the ageing process (Oberg and Tornstam 2003). Therefore the illustrations of Grandma with her apron and kerchief in the 21st century can actually serve as a feminist protest (to appear in "house clothes" without getting ready first, because that is the most comfortable) and not as a stereotypical approach.

\section{Illustrations of grandmothers cooking porridge: Choice or necessity?}

An illustrated book is written and "read" in two languages - verbal and visual - differentiated by the way they are presented and absorbed. When children's literature uses two languages simultaneously, it intensifies the representation of false reality as if it was a faithful rendering of reality. Therefore, children's literature fulfills an important role as an agent of socialization in structuring and reproducing the reality, through which the identity of the society in which it was created, its dilemmas and main narratives can be examined (Danino-Yona 2009). Many of us have emblazoned in our childhood memories, Grandma toiling over the stove, preparing food that her grandchildren particularly liked.

The "Savta bishlah daysah" [Grandma cooked porridge] rhymes are the cultural basis connecting between grandmothers and their grandchildren, through the kitchen - a Diaspora past interfacing with a present Israeli reality. In the books Savta shel Naftali Bishlah Daysah [Naftali's grandma cooked porridge] by Alona Frankel (2007) (see Figure 4) and Savta shel Hannah Bananah Bishlah Daysah [Hannah Banana's grandma cooked porridge] written and illustrated by Ora Eyal (2013) (see Figure 5), the grandmother is in the kitchen and essentially fulfils the stereotypical role expected of her, even though this role was more fitting during the 1960s when all the cookery books had instructions in feminine form [in Hebrew, the verb forms have masculine and feminine forms].

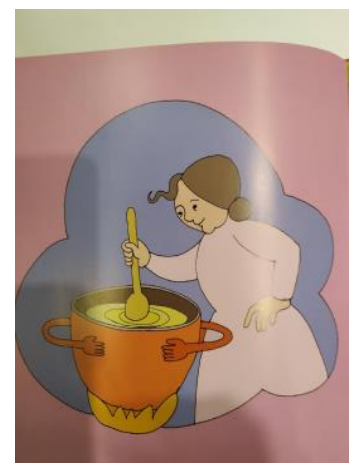

Figure 4. Savta shel Naftali Bishlah Daysah - illustration from inside the book

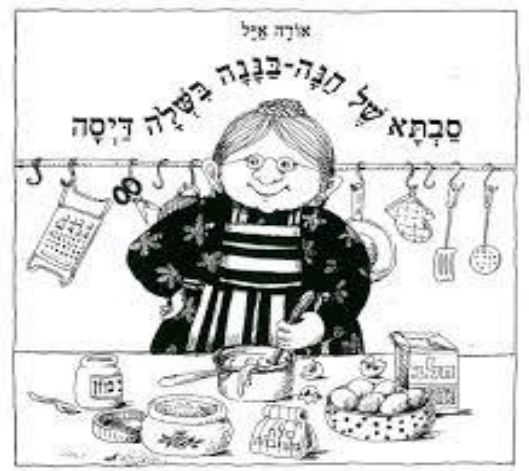

Figure 5. Savta shel Hannah Bananah Bishlah Daysah - front cover

Yeladim, Mitbah, Kenisiya [Children, kitchen, church] (in German: Kinder, Küche, Kirche or the three Ks) is a German expression, intended to describe the women's world and role. It is assumed that the expression was already in use in nineteenth century society. Alona Frankel and Ora Eyal return the grandmother-woman to the kitchen in the 21st century, using stereotypical illustrations of the portrayal of the Diaspora grandmother, to 
create visual interpretation of the situation in which Grandma goes into the kitchen out of choice, not because she has to, and that the grandmothers of the 21 st century are also aware that the way to their grandchildren's heart passes, among other ways, through the kitchen and the traditional dishes, passed down from one generation to the next.

Porridge, from different grains, has always starred in children's literature as a staple food (such as in "Goldilocks and the Three Bears"). It creates a shared childhood memory for peoples and cultures, and serves as a nutritious food for soldiers. It is also known for being healthy, tying in with grandmother giving out folk remedies. On the symbolic level, when the grandchildren or children eat the food which a beloved figure prepared for them, they connect emotionally through the food to the figure, and see in the gesture of preparing them food, a sign of love, particularly when the culinary activity is done together.

\section{Illustrations of grandmothers in jeans: Denial of old age}

"The remains of life are wisdom or folly and the choice is yours" (Leah Goldberg 1973, p. 279).

The ageing of the body begins from the moment of birth, and it is our basic state of existence, not only at the end of life (Porat 2013). The Mishnah (Ethics of the Fathers 5:21) divides a person's life into 14 stages: "At five years of age the study of Scripture; at ten the study of Mishnah; at 13 subject to the commandments; at 15 the study of Talmud; at 18 to marry; at 20 for pursuit [of livelihood]; at 30 for strength; at 40 wisdom; at 50 able to give counsel; at 60 old age; at 70 fullness of years; at 80 for mightiness; at 90 to stoop; at 100, as good as dead and has left this world". It can be seen that old age accounts for five out of the fourteen stages. Childhood and adolescence account for five or six stages, and the main and longest part of a person's life is reduced to only three or four stages. Beyond the differences between cultures and periods, dividing a person's life into stages defines each one according to a person's mental and physical condition. There are always transition ceremonies between childhood and adulthood, from the single stage to married life, and from the working stage to retirement. Psychoanalysts Freud and Erikson, along with playwright William Shakespeare in his work, As You Like It - in which he divided life into seven stages - also addressed dividing life into different stages.

The extended life expectancy comes with many difficult challenges - children in no hurry to grow up, young people not rushing to commit themselves to marriage, and adults refusing to grow old. The last of these has trickled into illustrations in children's literature, in which grandmothers are drawn to be as young mothers. For hundreds of years women have been told that they are defined by their bodies, and they have been sent a double message - men valued them for their beauty and they, on their own part, adapted themselves to the norms of this world, while they were simultaneously seen as shallow, always busy with their bodies (Rotstein Mayer 2005).

It would seem that "grandmothers in jeans" in children's book illustrations continue to define themselves by their bodies. In the books Savta B'Jins [Grandma in jeans] written by Tzivia Aurbach and illustrated by Lana Luketski (2001) (Figures 6, 7), and Savta Sheli B'Jins [My grandma in jeans] written by Dalia Gara (2010) and illustrated by Rotem Omri (Figures 8,9), we see active grandmothers with youthful bodies, tight jeans, and wrinkle-free faces who are fighting old age and perhaps even denying it, and refuse to accept it as an integral part of life.

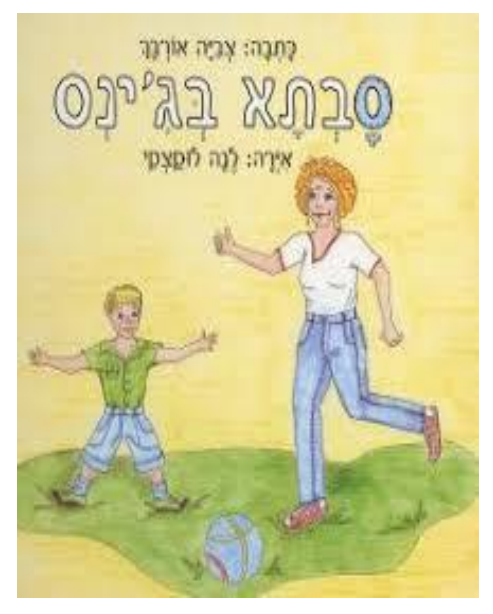

Figure 6. Savta B'Jins - front cover 


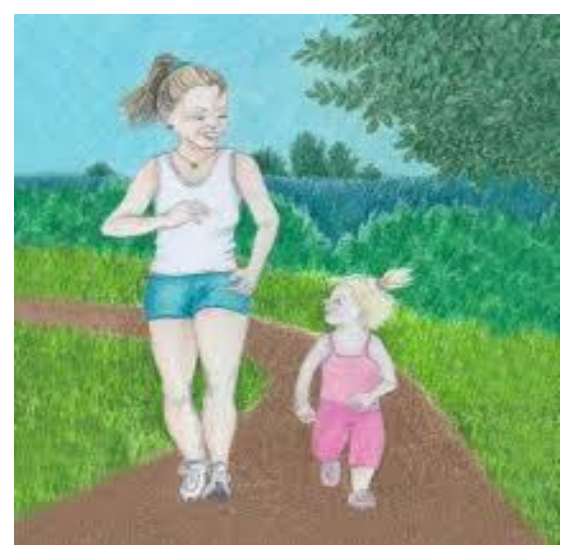

Figure 7. Savta B'Jins - illustration from inside the book

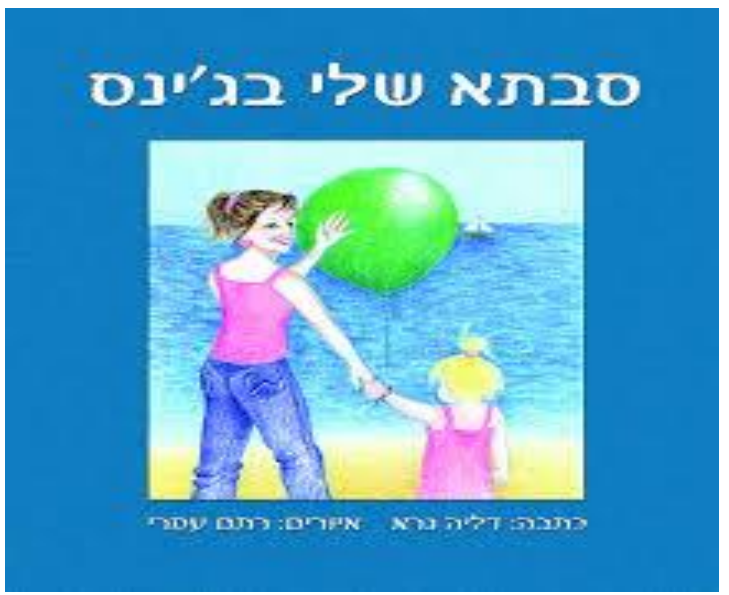

Figure 8. Savta Sheli B'Jins - front cover

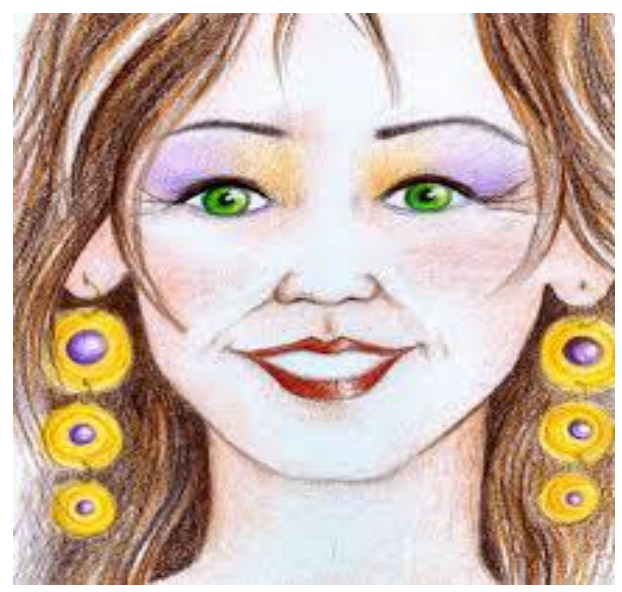

Figure 9. Savta Sheli B'Jins - illustration from inside the book

The erasure of old women's faces from the public arena, television, advertisements, and all kinds of media discourse, reinforces the collective fear of old age, as well as the fear of illustrators to draw an old grandmother. Where are the old faces? Why are they not shown? Faces revealing old age will reduce the fear of it. Just as salespeople do not promote sales with old faces, some children's illustrators are afraid to draw old people's faces to promote their children's books. Covid-19 has also set chronological, rather than mental age, functioning ability, or the extent to which someone is socially active, as a defining criteria for at-risk groups, and thereby determined categories according to which even if a grandmother wears jeans, collects her grandchildren from 
preschool twice a week, subscribes to concerts, and is planning an African safari this summer, she is still "old", and her entire existence is now defined by one sole variable - a damaged body with death just around the corner.

\section{Fashionable grandmothers - Attention! I'm not yet old!}

Denial of old age and exchanging the term for the optimistic paradigm of "high functioning", "health at every age", and "a wide range of activities for the third age" is common in the modern, industrialized world. There have been changes regarding the body in our times. What was once considered unaesthetic (thinness) has become beautiful and attractive, and what was a source for respect in earlier generations (old age) now arouses disdain. At the stage of middle age and becoming a grandmother, some try to struggle to hide old age from others and from themselves. They are not as extreme as the grandmother in jeans, they are aware of old age, but they attempt to distance themselves from the inevitable with fashionable clothing.

The illustrators of fashionable grandmothers will not draw grandmothers in jeans and with youthful bodies, but they still do not have the openness to define the body, soul, and gender. Their unwillingness to accept the human body as undergoing change in old age, the refusal to accept the unaesthetic appearance, stops them from drawing an aging body, and they try to make it look more attractive with flattering clothes or fashionable accessories.

In Tzintzenet Hadema'ot Shel Dvir [Dvir's jar of tears] by Mazal Savner and illustrated by Boaz Gabai (2008), we meet a grandmother with a short, spiky haircut, several necklaces, glasses dangling but not on her eyes, earrings, and a tight-fitting top which emphasizes her body curves (see Figure 10). The grandmother in the book Savta Minna Mibinyamina [Grandma Minna from Binyamina] by Datia Ben Dor and illustrated by Vitali Minin (2009) wears fashionable glasses and a tight-fitting suit (see Figure 11). Her hair is dyed red. Savta Shel Shabbat [Sabbath with grandma] by Yael Mishaly, illustrated by Yaara Buchman-Nota (2011), features a grandmother with a fashionable ribbon in her hair and a relatively short skirt (see Figure 12). In Hamasa Hakasum Shel Savta Tamar [Grandma Tamar's magical journey] by Tamar Chen, illustrated by Moran Dayan (2020), the grandmother wears red shoes, wraps a red scarf around her neck, and has long, loose hair (see Figure 13). Denial of old age is essentially denial of death which certainly awaits us at its end, a denial that has perhaps existed for the history of mankind. But the grandmothers in these illustrations remind us that old age also has positive and liberating aspects.

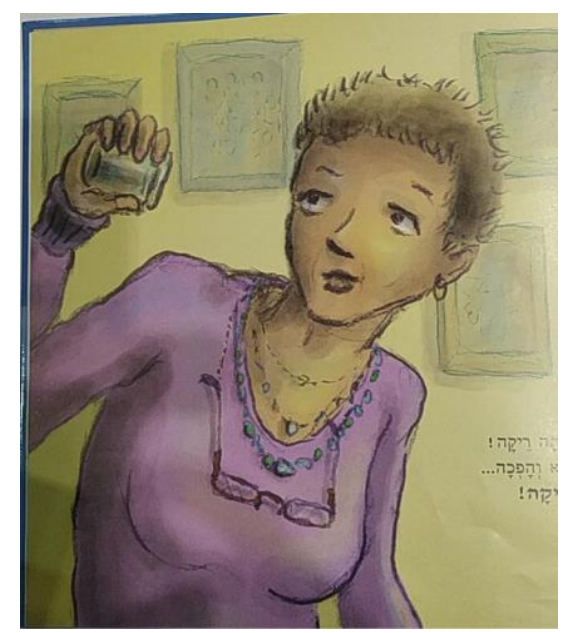

Figure 10. Tzintzenet Hadema'ot Shel Dvir - illustration from inside the book 


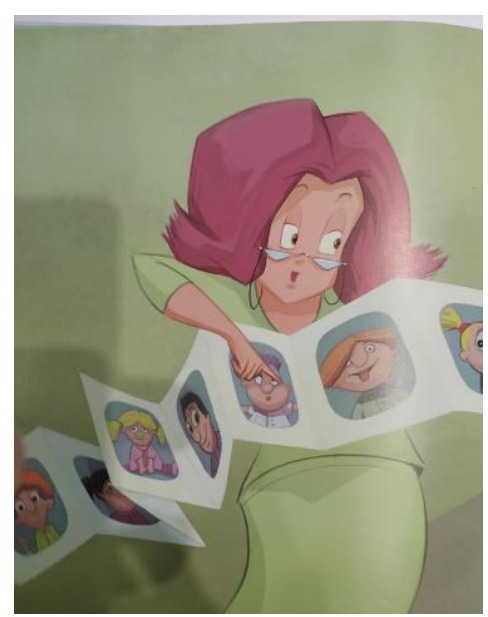

Figure 11. Savta Minna Mibinyamina - illustration from inside the book

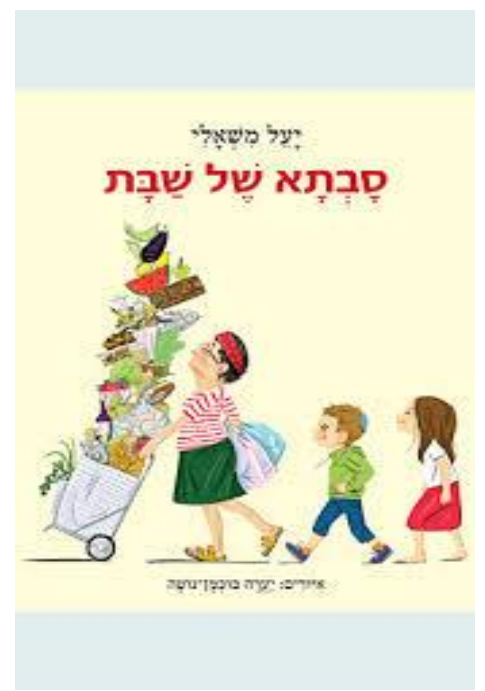

Figure 12. Savta Shel Shabbat - front cover

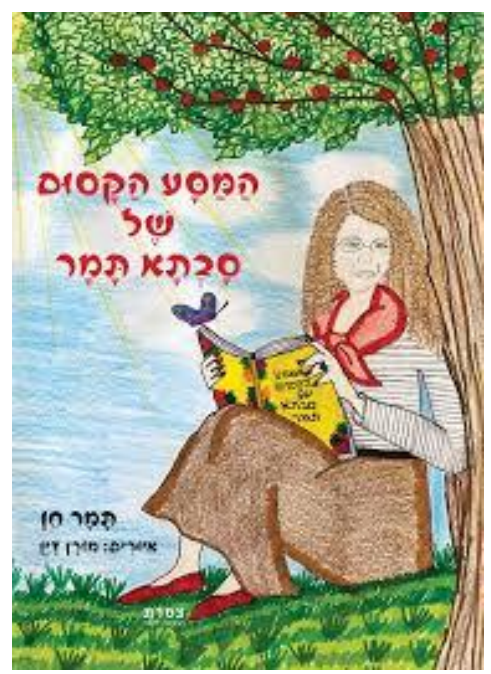

Figure 13. Hamasa Hakasum Shel Savta Tamar - front cover 


\section{Grandmothers' self-fulfillment}

The positive sides of old age are the search for the spiritual dimension as part of the various occupations and varied self-awareness techniques. The spiritual dimension of the New Age respects the old woman as an observer. In the book K'shesabati Lashuk Yatsah [My granny went to market] by Mirik Snir, illustrated by Christopher Corr (2007) (see Figures 14, 15), the grandmother goes out (alone, with white hair and deliberately not colored) to tour the world. She travels to the frozen tundra of Siberia, the African jungles, and other exotic places. The social selection theory (SST) suggests that a person's motivation to act is directly influenced by his subjective perception of how long he has left to live, and not necessarily by his objective age, goals, preferences, or way of thinking. When the future is seen as long and death as far off, there is a tendency to set goals connected to gathering information and expanding horizons; these aims particularly emphasize goals for nurturing emotions and emotional well-being (Carstensen 2006).

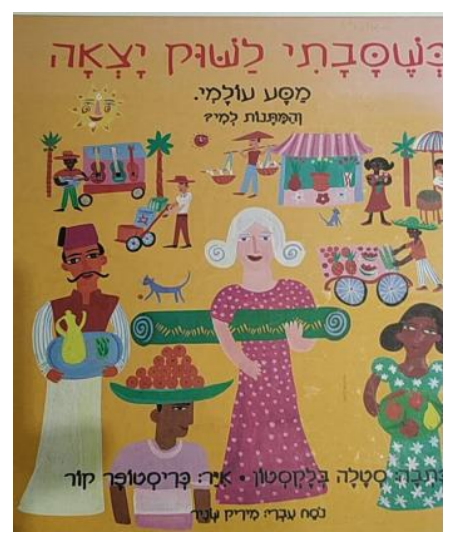

Figure 14. K'shesabati Lashuk Yatsah - front cover

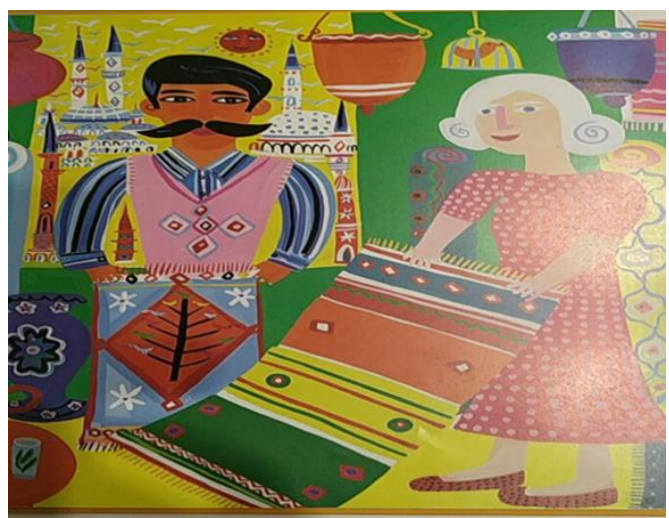

Figure 15. K'shesabati Lashuk Yatsah - illustration from inside the book

In Hello Savta, Zu Ani Medaberet [Hello grandma, it's me speaking] by Yemima Avidar-Tchernovitz, illustrated by Elisheva Gaash (1988) (see Figures 16, 17), we meet a sculptor grandmother who continues creating her art while speaking to her granddaughter, on a modern, hands-free telephone. Sometimes connection with artistic creation is needed to create meaningfulness in old age. Involvement with various fields of art enables grandmothers to find meaning in their lives after retirement and to be free and liberated to create what they really want to, while strengthening their relationship with their grandchildren, rather than the creativity being a substitute for that connection. The phone conversation is equally important to both grandmother and granddaughter. 


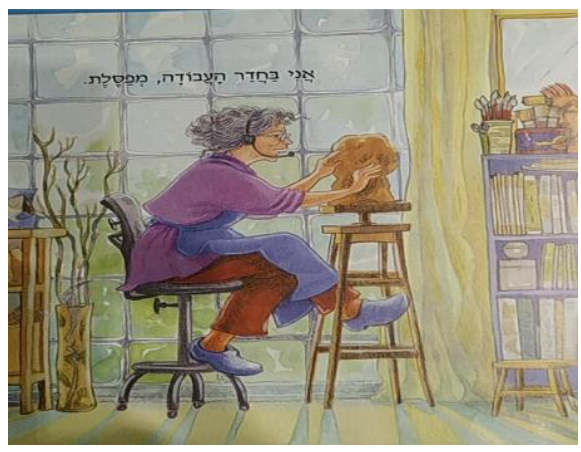

Figure 16. Hello Savta, Zu Ani Medaberet (1988) - front cover

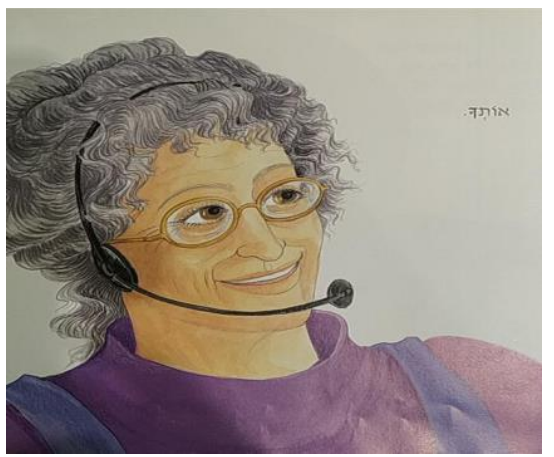

Figure 17. Hello Savta, Zu Ani Medaberet (1988) - illustration from inside the book

In comparison, note the illustrations in the same book, published five years earlier, in Hello Savta, Zu Ani Medaberet [Hello grandma, it's me speaking] by Yemima Avidar-Tchernovitz, illustrated by Yiftah Allon (1983), in which the grandmother looks completely different from the sculptor grandmother from 1988 (see Figure 18).

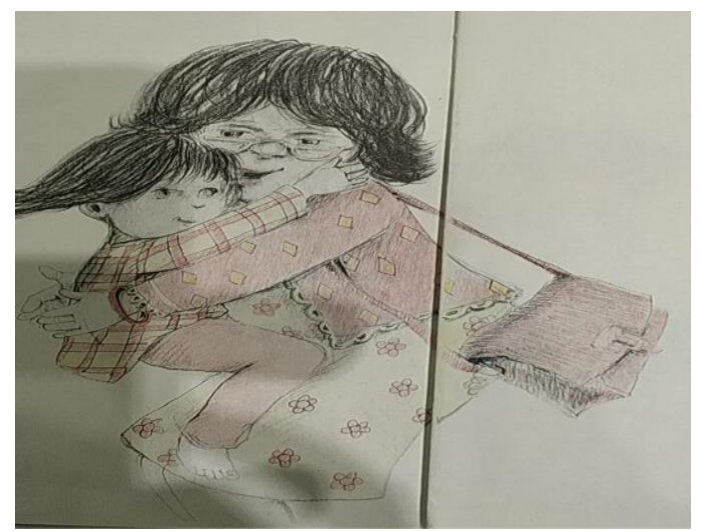

Figure 18. Hello Savta, Zu Ani Medaberet (1983) - illustration from inside the book

\section{Fun-loving grandmothers}

Several decades ago, researchers believed that textbooks and story books for children were full of unequivocal gender-based stereotypes which described women as inferior to men regarding their talents and roles (see, for example: Krasni 2005; Meller 1991). Certainly grandmothers were never seen having fun with their grandchildren.

In the books, Savta Od Pa'am [Again, grandma] by Edna Mazya (2010), illustrated by Orna Smorgonsky (see Figure 19), Lishon Etsel Savta [Sleeping at grandma's] by Nira Harel, illustrated by Hadar Geva (2014) (see Figures 20a-d), and Ma Osim im Savta [What can we do about grandma?] by Edna Mazya, illustrated by Orna Smorgonsky (2017) (Figures 21a-d), the grandmothers are portrayed as if their entire essence is their ability to 
go back to being little girls. They romp with their grandchildren, happily play a sociodramatic game, ride scooters or bicycles, and their weight or hair color doesn't really interest them. One of the reasons for old age being perceived as so threatening is the thought that brain activity degenerates as people age. The picture of the senile, confused, or tactless old man creates an erroneous view of old people's capabilities, needs, and how to relate towards them. The old person, who demand things "little and slowly" contradicts the life of people in the Western world full of "a lot and quickly". The grandmothers who play in their children's books are not senile or confused. They aren't hurrying anywhere - not to a class, not to work, not to a career, and not for time to themselves. They devote all their time to their grandchildren, and feel younger and more like mothers than grandmothers.

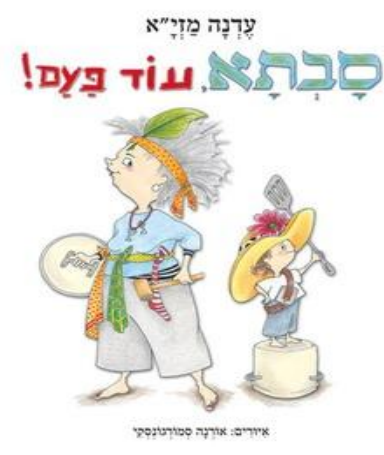

Figure 19. Savta Od $\mathrm{Pa}$ 'am - front cover
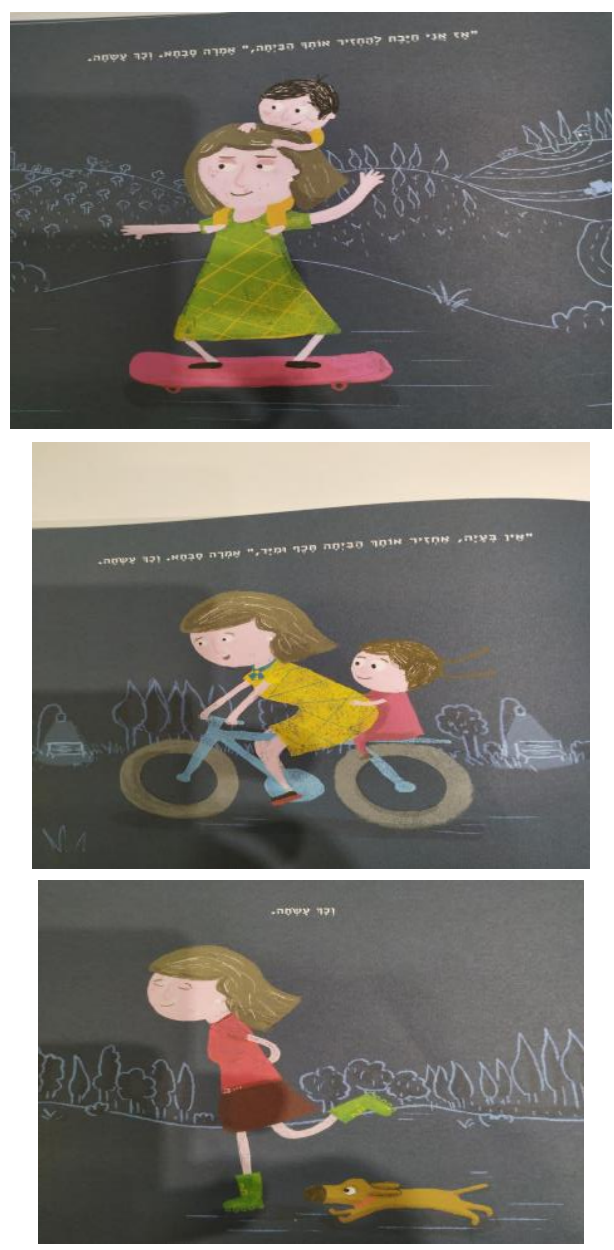


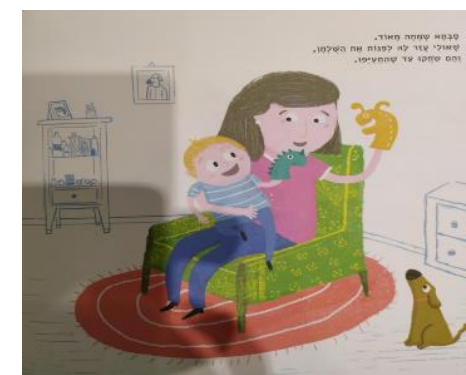

Figures 20a-d. Lishon Etsel Savta - illustrations from inside the book
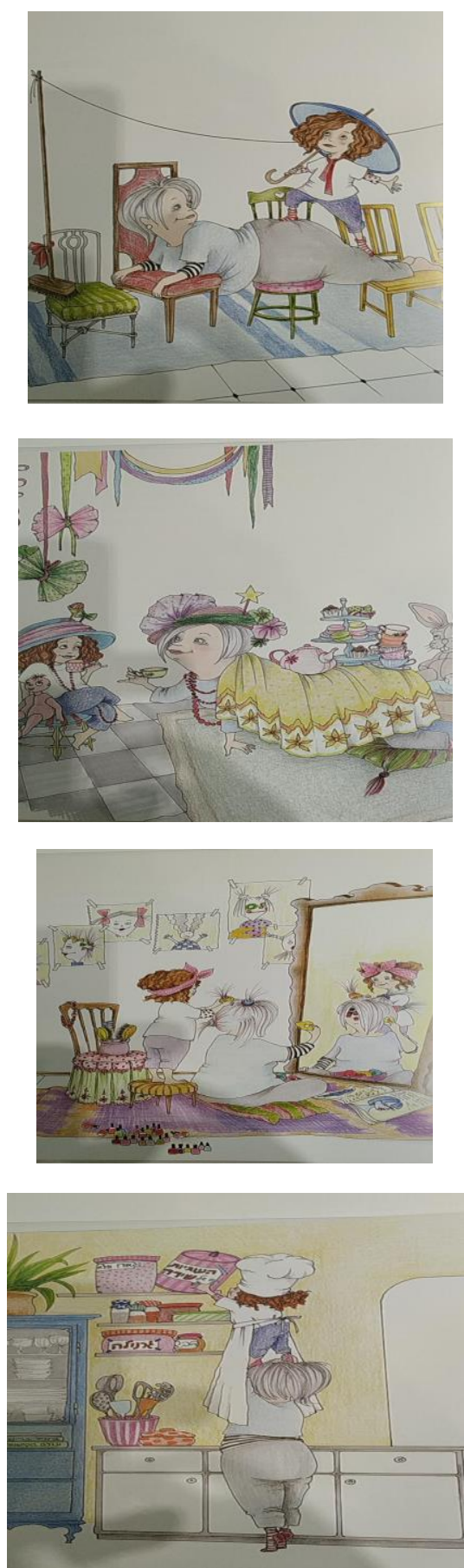

Figures 21a-d. Ma Osim im Savta - illustrations from inside the book 


\section{Grandmothers who relate to their grandchildren through their own childhood}

In the book, Savta Sipri Li Sipur [Grandma, tell me a story] by Nitsa Dori, illustrated by Yael Lurie (2014) (see Figures 22a-b), the grandson asks his grandmother to tell him a story. The grandmother suggests different types of stories - humorous, frightening, and happy, but the grandson doesn't want them. In the end his grandmother tells him a story about a girl who lived with her family in a house in the middle of a forest and she had her own tree, which she planted and nurtured. One day a fire destroyed all the trees in the forest, but her tree remained unharmed and was not burned. At the end of the story, the grandson discovers that his grandmother told him a true story about herself that happened when she was a little girl, and he asks if she can take him to see the tree. The story was written after the Mount Carmel Forest Fire of 2010, in an attempt to explain to young children the importance of looking after forests, what can cause fires there, and our connection with Israel's greenery, scenery, earth, and roots, a connection which leads to a no less important, warm, and special connection between grandmother and grandson.
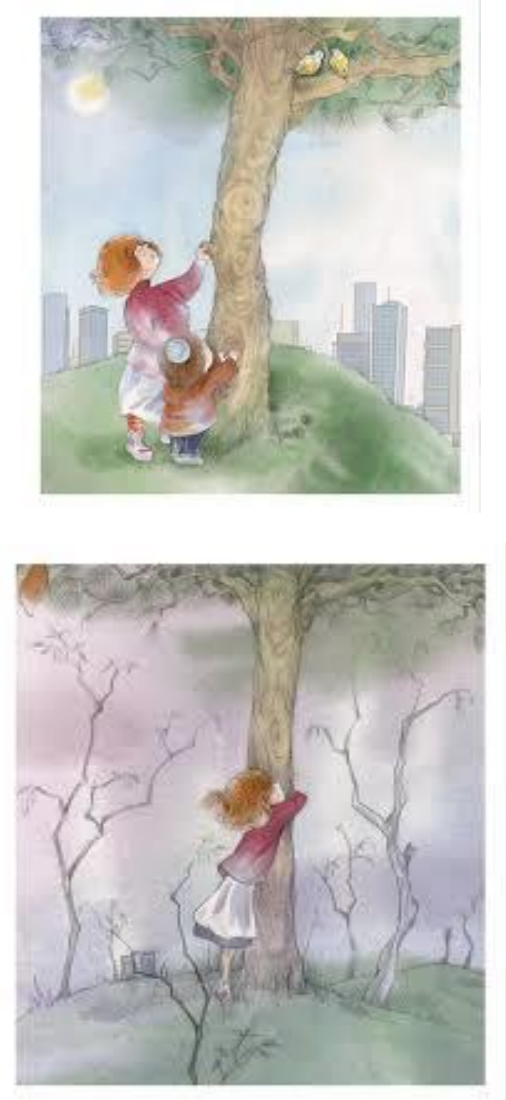

Figures 20a-b. Savta Sipri Li Sipur - illustrations from inside the book

The book includes two almost-identical illustrations of grandma as a girl and grandma as she is today - the same hair color and wearing almost the same color clothes, to portray to the children how that same girl in the picture will one day be a grandmother, and that same grandmother in the second illustration was once a child.

\section{Comparative study of illustrations of grandfathers in Hebrew children's literature}

Studying the illustrations of grandfathers in Hebrew children's books from different periods, demonstrates that the grandfather figure underwent many metamorphoses - the grandfather usually has white hair, a beard or mustache, and wears regular, everyday clothes. He can appear as a farmer or manual worker (Simlat Hashabat Shel Hanna'le by Yitzhak Schweiger Demiel (1937); Eliezer Vehagezer by Levin Kipnis (1964); Hageshem shel Saba Aharon [Grandpa Aaron's rain] by Meir Shalev (2007), and Hatraktor Ha'adom shel Saba Arnon [Grandpa Arnon's red tractor] by Arnon Raviv (2019)). In recent years, the grandfather has also appeared as a character going silly with his grandchildren (Vanil Al Hametsah Vetut al Ha'af [Vanilla on his forehead and strawberry on his nose] by Meir Shalev (2013); Saba Kontsoni [Grandpa Kontsoni] by Achiya Zallayet (2016); Eich Oseh Saba 
[What noise does Grandpa make?] by Nira Harel (1995)), and as someone who cooks (Saba Sabiah [Grandpa Sabiah] by Tami Shem Tov (2017)).

The characters of the grandfathers do not try to look young or deny old age like the grandmothers do. Most of the contemporary stories and songs about grandfathers or grandmothers describe wonderful, pleasant, warm, and loving figures. Many of the characters are blessed with a sense of humor, a great deal of knowledge, and endless patience. We read about the harmony which exists between grandfathers and their grandchildren. They have shared interests. The grandfather understands the child (more than the parent does), and the grandchild responds to this understanding. The grandfathers are painted as fascinating people who arouse interest and love among the children and are happily welcomed by them (Yaar-Weisel 2006).

However, there are several interesting phenomena which reflect a significant change in Israeli society along with advancement and technology. They invite the grandchildren, grandfathers, and grandmothers, to step into the big, wide world through television, the DVD, and the cell phone. In A. B. Joshua's book, Hayat Hamahmad shel Ofri [Ofri's pet] (2007), Grandma throws Grandpa out of the house "because she doesn't like it when he stands behind her when she's sitting at her computer", and the grandmother in Saba Sabiah (Shem Tov 2017) goes shopping arm in arm with the grandfather. Two illustrated incidents which did not exist in previous decades in Hebrew children's literature.

\section{Conclusion}

In this article, we have encountered various illustrations of grandmothers from different eras of children's literature - drawings of grandmothers with glasses, aprons, and kerchiefs, along with pictures of grandmothers making porridge, some of which testify to a stereotypical view and others to a post-feminist approach (dependent on the period); pictures of grandmothers in jeans expressing a denial of old age; fashionable grandmothers who do not necessarily indicate such denial but rather of maintaining a well-groomed and aesthetic image; illustrations of grandmothers who are fulfilling themselves not necessarily by looking after their grandchildren, but rather by doing activities which they enjoy, and pictures of grandmothers romping with their grandchildren and playing like little girls, riding bicycles and more.

The conflictual space between verbal and visual language enables the existence of a new interpretative field which blurs and challenges the hierarchy between the generations (Danino-Yona 2009). The effect of the words on the illustrations, and vice versa, emanates from the power of the words to change our visual interpretation of the picture, and the power of the picture to change our interpretation of the words and their meaning. The visual interpretation of the illustrations imparts the various stories with other meanings and creates visual narratives which strengthen the text itself. The findings in this article show that children's literature, including illustrators of children's literature, can influence how children understand reality and contribute to their initial structuring of the ideas to which they are exposed (Baratz and Zamir 2007, pp. 374-386; Sacerdoti 2013; Schwarcz 1968, pp. 393-400; Shavit 1996, pp. 124-145, 182-197, 266-277). Illustrated children's literature includes textual and visual dimensions, with the importance of each and the relationship between them dependent on the specific book.

Carey (2009) describes in detail the way each small child understands the world - an important part of the conceptualization takes place through how the child reacts to sensual stimuli, in a manner which enables the child to identify with the text. W. Roth (2002) mentions the experience a person has when seeing things. The possibility of looking at new visual images enables the person to recreate his world, while imparting emotional meaning to the illustrations. W. Roth argues that the process of seeing with repeated contemplation can empower the person with a different experience of seeing, since each time new, previously unnoticed components are added. The ways a particular visual picture is contemplated vary each time, depending on the emotional state of the person contemplating it on that particular day as compared with a different day, and on his different experiences between the first time he looks and the next. Tur Gonen (1995) emphasizes: "The illustrated book for young children fulfils an important role in nurturing the child's ability to understand the intentions of the visual messages, and in learning the special rules of the visual language."

In today's books, the grandmothers appear more connected to advanced technology than ever. The grandmothers of the previous century spoiled their grandchildren in their homes with food and stories, whereas the grandmothers of our times spoil them also in a totally different manner - they are entrepreneurial, use new technology, are familiar with all the brand names, and spending time with them usually involves being outside the house (Baruch 2008). The illustrators of today's children's books will connect with the model of the new grandmother and draw her wearing jeans and without wrinkles. At the same time, we can also see traditional grandmothers (with grey hair, glasses, and an apron) in certain illustrations in recently published books, from a 
post-feminist approach, rather than a stereotypical one.

\section{References}

Agnon, S. (1959). Hashanim Hatovot [The good years]. In S. Agnon (Ed.), Elu V'elu [These and those]. Tel Aviv: Schocken.

Aurbach, T. (2001). Savta B'Jins [Grandma in jeans]. Hod Hasharon: Lior Saraf.

Avidar-Tchernovitz, Y. (1983). Hello savta, zu ani medaberet [Hello grandma, it's me speaking]. Moshav Ben Shemen: Keter.

Avidar-Tchernovitz, Y. (1988). Hello savta, zu ani medaberet [Hello grandma, it's me speaking]. Moshav Ben Shemen: Keter.

Avnon, Y. (1960). Savta mesaperet [Grandma tells]. Tel Aviv: Amihai.

Baratz, L., \& Zamir, S. (2007). B'tsomet safot - Sifrut yeladim ketuvah aravit [At the junction of languages Written Arabic children's literature]. Jama, 11, 374-386. Retrieved from http://www.qsm.ac.il/mrakez/asdarat/jamiea/11/heb--5--leeaa\%20bartez.pdf

Baron, D. (1968). Nekhadim [Grandchildren]. Jerusalem: Mossad Bialik.

Baruch, M. (2008). Temurot b'itsuv hasabim bamishpaha b'sifrut hayeladim bat zemanenu [Changes in the depiction of grandfathers in the family in contemporary children's literature]. Moznaim, 3/4, 2-6. Retrieved from https://www.jstor.org/stable/23964550

Ben Dor, D. (2009). Savta Minna mibinyamina [Grandma Minna from Binyamina]. Moshav Ben Shemen: Modan.

Bergson, G. (1987). Tshok bein kematim: Sabim v'nekhdeihem b'sifrut hayeladim ha'ivrit [Laughter among the wrinkles: Grandparents and their grandchildren in Hebrew children's literature]. Tel Aviv: Dvir.

Brick, Y., \& Lowenstein, A. (Eds.) (2010). Hazaken vehamishpachah: Sugiyot merkaziyot b'yahasim rav doriyim [The old person and the family: Central issues in multigenerational relationships]. Jerusalem: Eshel.

Carey, S. (2009). The origin of concepts. Oxford: Oxford University Press. https://doi.org/10.1093/acprof:oso/9780195367638.001.0001

Carstensen, L. L. (2006). The influence of a sense of time on human development. Science, 312, 1913-1915. https://doi.org/10.1126/science.1127488

Chen, T. (2020). Hamasa hakasum shel savta Tamar [Grandma Tamar's magical journey]. Petah Tikva: Tzammeret.

Danino-Yona, G. (2009). Hatranut vizualit besifrei yeladim ha'oskim beyahasim bein-doriyim [Visual subversion in children's books on the subject of intergenerational relationships]. Bein Hashurot, 3, 155-191. Retrieved

from https://www.academia.edu/attachments/63248690/download_file?st=MTYyMDA2NTczOSw3OS4xNzYu NTIuMTA3\&s=swp-splash-paper-cover

Dar, Y. (2007, March 29). Pitom kulam rotsim lishmo'a sipurei savta [Suddenly everyone wants to hear grandmothers' stories]. Ha'aretz, Retrieved from https://www.haaretz.co.il/literature/youngsters/1.1399256

Demiel, Y. S. (1937). Simlat hashabat shel Ḥanna'le [Hanna'le’s Sabbath dress]. In Devar Leyeladim.

Dori, N. (2014). Savta sipri li sipur [Grandma, tell me a story]. Haifa: Shaanan College.

Dori, N. (2018/9). Hagehakhat dmut ha'ishah besifrut yeladim: Mistereyotip migdari l'meha'ah feministit [Ridiculing the woman's image in children's literature: From a gender-based stereotype to a feminist protest]. Hemdaat, $11 . \quad$ Retrieved from https://www.hemdat.ac.il/wp-content/uploads/2019/07/1\%D7\%A0\%D7\%99\%D7\%A6\%D7\%94-\%D7\%93 \%D7\%95\%D7\%A8\%D7\%99-\%D7\%94\%D7\%92\%D7\%97\%D7\%9B\%D7\%AA-\%D7\%93\%D7\%9E\%D7 \%95\%D7\%AA-\%D7\%94\%D7\%90\%D7\%99\%D7\%A9\%D7\%94-\%D7\%91\%D7\%A1\%D7\%A4\%D7\%A8 \%D7\%95\%D7\%AA-\%D7\%99\%D7\%9C\%D7\%93\%D7\%99\%D7\%9D.pdf

Eagly, A. H. (1987). Sex differences in social behavior: A social-role interpretation. Hillsdale, NJ: Lawrence Erlbaum.

Eyal, O. (2013). Savta shel Hannah Bananah bishlah daysah [Hannah Banana's grandmother cooked porridge]. Israel: Ayalot. 
Frankel, A. (2007). Savta shel Naftali bishlah daysah [Naftali's grandmother cooked porridge]. Moshav Ben Shemen: Keter.

Gara, D. (2010). Savta sheli b'jins [My grandma in jeans]. Yehud-Monosson: Ofir Bikurim.

Gilligan, C. (2011). Joining the resistance. Cambridge: Polity Press.

Goldberg, L. (1971). She'erit hahayim [The remains of life - poems]. Bnei Brak: Hakibbutz Hameuhad.

Hagestad, G. O. (1985). Continuity and connectedness. In V. L. Bengston, \& J. F. Robertson (Eds.), Grandparenthood (pp. 31-48). Beverly Hills, CA: Sage.

Harel, N. (1995). Eich oseh Saba [What noise does Grandpa make?]. Tel Aviv: Am Oved.

Harel, N. (2014). Lishon etsel savta [Sleeping at grandma's]. Rishon Lezion: Zebra.

Hunt, P. (2004). Introduction: The expanding world of children's literature studies. In Peter Hunt (Ed.), Understanding children's literature (2nd ed., pp. 1-14). London: Routledge.

Joshua, A. B. (2007). Hayat hamahmad shel Ofri [Ofri's pet]. Bnei Brak: Hakibbutz Hameuhad.

Kipnis, L. (1964). Eliezer vehagezer [Eliezer and the carrot]. Shmuel Zimzon.

Kivnick, H. Q. (1982). The meaning of grandparenthood. Ann Arbor, MI: UMI Research Press. https://doi.org/10.1037/t05933-000

Krasni, A. (2005). Hatefisah hasteriotipit shel demut ha'ishah besifrut yeladim [The stereotypical approach of the portrayal of the woman in children's literature]. Shaanan, 10, 197-216.

Lemaster, P., Delaney, R., \& Strough, J. (2017). Crossover, degendering, or...? A multidimensional approach to life-span gender development. Sex Roles, 76, 669-681. https://doi.org/10.1007/s11199-015-0563-0

Lindsey, L. L. (2015). Gender roles: A sociological perspective (6th ed.). New York: Routledge. https://doi.org/10.4324/9781315664095

Liran-Alper, D., \& Kama, A. (Eds.) (2007). Itsuv haguf vehituv hazehut: Yitsugei haguf bateleviziyah hamisharit [Shaping the body and shaping identity: Depictions of the body on commercial television]. Tel Aviv: Chaim Herzog Institute for Media, Politics, and Society, Tel Aviv University. Retrieved from https://www.tau.ac.il/institutes/herzog/igarta7.pdf

Mazya, E. (2010). Savta od pa'am [Again, grandma]. Or Yehuda: Kinneret, Zmora-Bitan, Dvir.

Mazya, E. (2017). Ma osim im savta [What can we do about grandma?]. Or Yehuda: Kinneret, Zmora-Bitan, Dvir.

Meller, Z. (1991). Hishtakfut steriotipiyim miniyim besifrei limud behinukh hamamlakhti beyisrael [The transparency of sexual stereotypes in textbooks in Israel's state schools]. Hahinukh Vesvivo, 86-100.

Mishaly, Y. (2011). Savta shel Shabbat [Sabbath with grandma]. Or Yehuda: Kinneret, Zmora-Bitan, Dvir.

Nikolajeva, M., \& Scott, C. (2000). The dynamics of picturebook communication. Children's Literature in Education, 31, 225-239. https://doi.org/10.1023/A:1026426902123

Nikolajeva, M., \& Scott, C. (2001). How picturebooks work. New York: Garland.

Nodelman, P. (1988). Words about pictures: The narrative art of children's picture books. Athens, GA: University of Georgia Press.

Oberg, P., \& Tornstam, L. (2003). Attitudes towards embodied old age among Swedes. International Journal of Aging and Human Development, 56, 133-153. https://doi.org/10.2190/CDGJ-6WFA-HXA2-X967

Porat, G. (2013). Ra'ayon im prof dov shmotkin: 'Ziknah hi lo rak inyan shel zekeinim vehokrim. Hu noseh kiyumi hidati l'adam bekhol gil [An interview with Prof. Dov Shmotkin: 'Old age is not only for old people and researchers. It is an existential and enigmatic issue for people of all ages']. Dorot, 150, 18-22. Retrieved from https://herczeg.tau.ac.il/images/articles/Shmotkin_Interview.pdf

Raviv, A. (2019). Hatraktor ha'adom shel Saba Arnon [Grandpa Arnon's red tractor]. Rishon Lezion: Orion.

Roth, M. (2002). Hahatulim shel savta Na'omi [Grandma Naomi’s cats]. Bnei Brak: Sifriat Poalim.

Roth, W. (2002, April). From stimulus to science: The changing nature of visual perception. Talk conducted at the Annual Meeting of the American Educational Research Association, New Orleans.

Rotstein Mayer, V. (2005). Yitsug haguf hanashi - Erum ukesut etsel amaniut yisraeliyot [The portrayal of the 
female body - Nakedness and clothing among Israeli artists]. Retrieved March 10, 2021, from https://www.varda-art.co.il/99888/\%D7\%9B\%D7\%A1\%D7\%95\%D7\%AA-\%D7\%95\%D7\%9C\%D7\%91\% D7\%95\%D7\%A9-\%D7\%91\%D7\%90\%D7\%9E\%D7\%A0\%D7\%95\%D7\%AA-\%D7\%94\%D7\%99\%D7\%A 9\%D7\%A8\%D7\%90\%D7\%9C\%D7\%99\%D7\%AA

Sacerdoti, Y. (2013). Ani lo bediyuk mah sheratsitem: Al mifgashim bein hayeled 'hatipusi' layeled 'ba'al hatsrakhim hameyuhadim' besifrut hayeladim hayisra'elit [I'm not exactly what you wanted: About meetings between the 'typical' child and the child 'with special needs' in Israeli children's literature]. Dvarim. Retrieved from http://app.oranim.ac.il/dvarim/2013/11/yaakova-sacerdoti/

Sagan, N. (Ed.) (1995). Matsa min et shivyono [Each sex has found its equal]. Jerusalem: Israel Ministry of Education.

Savner, M. (2008). Tzintzenet hadema'ot shel Dvir [Dvir's jar of tears]. Rishon Lezion: Orion.

Schwarcz, J. H. (1968). Hashpa'ato hahinukhit shel hameya'er [The educational influence of the illustrator]. Hed Hagan, 32, 393-400. https://doi.org/10.1080/00131726809338758

Schwarcz, J. H. (2013). Tafkid hame'ayer behavayah ha'estetit shel hayeled [The role of the illustrator in the child's aesthetic experience]. Betzalel Ktav Et Letarbut Hazutit Vehomrit. Retrieved from https://journal.bezalel.ac.il/he/protocol/article/3464

Shalev, M. (2007). Hageshem shel Saba Aharon [Grandpa Aaron's rain]. Tel Aviv: Am Oved.

Shalev, M. (2013). Vanil al hametsah vetut al ha'af [Vanilla on his forehead and strawberry on his nose]. Tel Aviv: Am Oved.

Shani, A. (2019). Min, migdar, vehaguf hamizdaken: hakesher bein min, tafkidei migdar, gil cronologi vegil subyektivit lebushah gufanit begil haziknah [Sex, gender, and the aging body: The link between sex, gender roles, chronological age, and subjective age to body shame in old age]. (Unpublished master's thesis). Tel Aviv University, Tel Aviv.

Shavit, Z. (1996). Ma'aseh yaldut: Mavo lepo'etikah shel sifrut yeladim [Just childhood: Introduction to poetics of children's literature]. Tel Aviv: Open University of Israel.

Shem Tov, T. (2017). Saba Sabiah [Grandpa Sabiah]. Or Yehuda: Kinneret, Zmora-Bitan, Dvir

Snir, M. (2007). K'shesabati lashuk yatsah [My granny went to market]. Tel Aviv: Agam.

Szinovacz, M. E. (1998). Research on grandparenting: Needed refinements in concepts, theories, and methods. In M. E. Szinovacz (Ed.), Handbook on Grandparenthood (pp. 257-288). Westport: Greenwood Press.

Tal-Shitrit, N. (2008). Hahayim besaba'ut [Life as a grandfather]. Psychiologiyah Ivrit. Retrieved from https://www.hebpsy.net/articles.asp?id=1698

Tur Gonen, R. (1995). Mesarim Erkiyim Besifrei-Yeladim Yisra'eliyi'im Meoyarim Legil Harakh B'shanim 1948-1984 [Principal messages in Israeli illustrated children's books for very young children]. Ma'agalei Kriyah, 23-24, 53-93.

Tur Gonen, R. (2013). Lehanot v'livkot: Iyur sifrut yeladim kemediyum transformativi mehashkahah lehankhahah shel sevel [To enjoy and to cry: Illustrating children's literature as a transformative medium from causing to forget to causing presence of suffering]. Betzalel Ktav Et Letarbut Hazutit Vehomrit. Retrieved from https://journal.bezalel.ac.il/he/protocol/article/3477

Yaar-Weisel, T. (2006). Demut ha'adam hazaken b'sifrut hayeladim hayisra'elit [The figure of the old person in Israeli children's literature]. Gerontologiyah: Ktav Et Benoseh Haziknah, 33(2), 35-54. https://doi.org/10.1556/AAlim.35.2006.1.5

Zallayet, A. (2016). Saba Kontsoni [Grandpa Kontsoni]. Tel Aviv-Yafo: Sa'ar.

\section{Copyrights}

Copyright for this article is retained by the author(s), with first publication rights granted to the journal.

This is an open-access article distributed under the terms and conditions of the Creative Commons Attribution license (http://creativecommons.org/licenses/by/4.0/). 